\title{
DIGITAL INCLUSION PROJECTS IN DEVELOPING COUNTRIES: Value, Sustainability, and Scalability
}

\author{
Shirin Madon \\ London School of Economics \\ London, U.K. \\ Nicolau Reinhard \\ University of São Paulo \\ São Paulo, Brazil \\ Dewald Roode \\ University of Pretoria and \\ University of Cape Town \\ Pretoria/Cape Town, South Africa \\ Geoff Walsham \\ University of Cambridge \\ Cambridge, U.K.
}

\section{INTRODUCTION}

It is increasingly recognized that the so-called digital divide is not just a matter of unavailability of information and communication technologies (ICTs), but also of the social, political, institutional, and cultural contexts that shape people's lack of access to ICTs, or their inability to use them effectively (e.g., Warschauer 2003). These problems apply to the socially excluded in all countries of the world, the "Fourth World" in the language of Castells (1998). However, it can be argued they are particularly acute in the developing countries, where large numbers of people do not have access to technology, nor the educational background or support to develop their skills in using technology to improve their own lives, or the lives of the communities within which they live.

One response to the above over the last decade or so has been a variety of digital inclusion projects in a wide range of contexts and countries. These projects normally

Please use the following format when citing this chapter:

Madon, S., Reinhard, N., Roode, D., and Walsham, G., 2006, in IFIP International Federation for Information Processing, Volume 208, Social Inclusion: Societal and Organizational Implications for Information Systems, eds. Trauth, E., Howcroft, D., Butler, T., Fitzgerald, B., DeGross, J., (Boston: Springer), pp. 67-70. 
aim not only to deliver ICT access to particular targeted groups, but also to provide various types of support for learning and capacity building. In this panel, we will draw on experiences from digital inclusion projects in three different countries and contexts. These involve telecenters in rural areas of India and urban areas of the city of São Paulo in Brazil, and a community-based ICT project in a rural township in South Africa.

We will address three particular questions during the panel. First, what has been the value of these projects? It is well-known in the IS field that the evaluation of the costs and benefits of technology is problematic, and this certainly applies to digital inclusion projects (see, for example, Reilly and Gómez 2001). Who has benefited from the projects and in what ways? How can we assess these benefits? One concern, for example, is that digital inclusion projects may miss the least-advantaged groups in the communities that they aim to serve and thus, ironically, produce a local form of digital divide within these communities.

Even if we can be reassured that a digital inclusion project is delivering value, a second key issue is the sustainability of the initiative over time. For example, most projects are started with funding from local or central government, aid agencies, or NGOs. However, long-term financial sustainability implies the need to develop indigenous funding sources and sustainable revenue streams. Sustainability is not just a matter of money, but also of the development of institutional arrangements for the continuity of staffing levels, and the long-term cultural and political support for the initiative from government officials, politicians, and the community itself.

Individual projects may deliver value and be sustainable, but the scope of such projects is often limited. A crucial issue for developing countries is scalability. Sahay and Walsham (2005) define scaling as the approach through which a product or process is taken from one setting and expanded in size and scope within that same setting and/or also incorporated in other settings. The unfortunate word replication is sometimes used for this process, which implies the copying of an initiative in a straightforward way. However, scaling of digital inclusion projects is not a simple matter of repeating a formula elsewhere, but a much more complex problem involving the development of a heterogeneous network constituted of technology, people, processes, and the institutional context.

\section{PANEL CONTENT AND ORGANIZATION}

Geoff Walsham will chair the panel session, and he will start the panel with an introduction to the context and purpose of digital inclusion projects in developing countries, as outlined above. He will then ask each of the other panelists to describe a particular project with which they have been involved. In particular, in addition to a brief description of the project, he will ask them to focus on issues of value, sustainability, and scalability related to their project. Each of the four panelists, including the chair, will talk for no longer than 15 minutes, allowing at least half an hour for audience participation and contribution.

Shirin Madon will describe her research work on the Akshaya telecenter project, which was launched as a pilot in Malapurram district of North Kerala, India, in November 2002. Within one year, the project was deemed a success as Malapurram was 
the first district in India to achieve 100 percent family e-literacy. However, measuring the value of the project in terms of e-literacy became less relevant as other implementation issues gained importance. Evaluation of Akshaya should be seen to consist of a process linked with organizational and institutional reform and long-term sustainability of the project. The presentation will discuss Akshaya's survival in terms of its ability to generate commercial activity and local content in key economic sectors such as health and agriculture. The presentation will also describe the roll-out phase of the project to seven other districts in Kerala. [Reference: Madon 2005]

Nicolau Reinhard will describe his research work on digital inclusion projects in the city of São Paulo, Brazil, a mega-city of 17 million people. The projects have involved the setting up of telecenters in poor areas of the city. The first telecenter was established in 2001 , but the number of such centres is now into the hundreds. Additional telecenter initiatives have taken place at the state and federal levels. Despite this success in establishing a large number of working telecenters, there are serious concerns in terms of the difficulty of demonstrating effectiveness and long-term sustainability. On the other hand, the projects are seen to be an important political issue, for example at times of elections, but further problems arise when administrations change. [Reference: Macadar and Reinhard 2002]

Dewald Roode will describe his involvement in, and lessons learned from, a socioeconomic development project at the rural community of Siyabuswa in South Africa, which included provision of ICTs. In particular, he will focus on the problems experienced when this project was scaled-up to four other deep-rural communities. He will analyze his experiences through the concept of the "socio-techno divide," and will argue that it is this divide that has to be addressed - not the digital divide. The sociotechno divide describes the gap between governmental, political, and technological attempts to achieve "development" objectives by providing access to digital communication technologies, and approaches where the focus is on people and their developmental needs. [Reference: Roode et al. 2004]

\section{ABOUT THE PANELISTS}

Shirin Madon is a senior lecturer in Information Systems at the London School of Economics. She is currently responsible for teaching a Master's course on IT and Development. Her research focuses on IT and governance reform in developing countries. She has had a long-term involvement in fieldwork in India, studying both back-end systems for development planning and administration, as well as front-end eservices and telecenter applications. Shirin can be reached at s.madon@, lse.ac.uk.

Nicolau Reinhard is a professor in the Business Department of the University of São Paulo, Brazil, from where he also received his Ph.D. His publications, research, and consulting interests are related to the use of ICTs in public administration, and the impacts of ICTs on organizations. He serves on the editorial board of several IT/IS journals, and on the program committees of IT management conferences. In conjunction with his doctoral students and other research collaborators, he has carried out research work for several years on telecenters in Brazil. Nicolau can be reached at reinhard@usp.br. 
Dewald Roode was director of the School of Information Technology at the University of Pretoria, South Africa, until his early retirement at the end of 2001 . He now holds positions as visiting professor at several South African universities, where he focuses mainly on supervisory work of doctoral students. For the last decade, his research group has centered on the use of ICTs to achieve sustainable socio-economic development in nural communities in South Africa. He chairs IFIP's TC8 on Information Systems, was a member of the Steering Committee of IFIP's World Technology Forum in 2003 and 2005, and the program chair of WITFOR 2005. Dewald can be reached at jdr@inbekon.com.

Geoff Walsham is a professor of Management Studies at Judge Business School, University of Cambridge, UK. His teaching and research is centered on the development, management, and use of information and communication technologies, and the relationship of ICTs to stability and change in organizations and societies. He has field experience in many different countries, including a number of developing countries in Asia, Africa, and Latin America. His publications include Interpreting Information Systems in Organizations (Wiley 1993), and Making a World of Difference: IT in a Global Context (Wiley 2001). Geoff can be reached at g.walsham@jbs.cam.ac.uk.

\section{References}

Castells, M. End of Millennium, Oxford, UK: Blackwell, 1998.

Macadar, M. A., and Reinhard, N. "Telecentros comunitários possibilitando a inclusão digital: um estudo de caso comparativo de iniciativas brasileiras," in Proceedings of the $26^{\text {th }}$ ANPAD Meeting (Associação Nacional dos Programas de Pós-Graduação em Administração), Information Systems Track (ADI), Salvador-BA-Brasil, September 22-25, 2002.

Madon, S. "Evaluating the Developmental Impact of e-Governance Initiatives: An Exploratory Framework," Electronic Journal of Information Systems in Developing Countries (20:5), 2005 , pp. 1-13.

Reilly, K., and Gómez, R. "Comparing Approaches: Telecenter Evaluation Experiences in Asia and Latin America," Electronic Journal of Information Systems in Developing Countries (4:3), 2001, 1-17.

Roode, D., Speight, H., Pollock, M., and Webber, R. "It's Not the Digital Divide, it's the SocioTechno Divide!," in Proceedings of the $12^{\text {th }}$ European Conference on Information Systems, Turku, Finland, 2004.

Sahay, S., and Walsham, G. "Scaling of Health Information Systems in India: Challenges and Approaches," in A. O. Bada and A. Okunoye (eds.), Proceedings of the $8^{\text {th }}$ International Working Conference of IFIP WG9.4, Abuja, Nigeria, May 26-28, 2005, pp. 41-52.

Warschauer, M. "Dissecting the 'Digital Divide': A Case Study of Egypt," The Information Society (19:4), 2003, pp. 297-304. 